\title{
IDENTIFICATION AND ANTIMICROBIAL ACTIVITY OF ACTINOMYCETES STRAINS ISOLATED FROM SAMPLES COLLECTED IN THE COASTAL AREA OF HUE, DA NANG AND QUANG NAM PROVINCES, VIETNAM
}

\author{
Cao Duc Tuan ${ }^{1,2,3}$, Le Thi Hong Minh ${ }^{1, ~}{ }^{凶}$, Vu Thi Quyen ${ }^{1}$, Nguyen Mai Anh ${ }^{1}$, Doan Thi Mai Huong ${ }^{1}$, \\ Chau Van Minh ${ }^{1}$, Pham Van Cuong ${ }^{1}$ \\ ${ }^{1}$ Institute of Marine Biochemitry, Vietnam Academy of Science and Technology \\ ${ }^{2}$ Hai Phong University of Medicine and Pharmacy \\ ${ }^{3}$ Graduate University of Science and Technology, Vietnam Academy of Science and Technology
}

To whom correspondence should be addressed. E-mail: 1hminhbk@gmail.com

Received: 18.7.2017

Accepted: 25.10.2017

\section{SUMMARY}

Microorganisms are of particular interest because of their ability to synthesize high-value secondary compounds and provide us with novel and diverse chemical structures. The most common source of antibiotics is Actinomycetes which provide around two-third of naturally occurring antibiotics, including many of medical importance. In this study, 81 strains of actinomycetes were isolated from 145 samples including: sediments, sponges, soft corals, echinoderms and starfish collected from three sea areas of Vietnam: Hue, Da Nang and Quang Nam. The strains were fermented in $\mathrm{A}^{+}$medium and fermentation broths were extracted 5 times with ethyl acetate. The extracts were evaporated under reduced pressure to yield crude extracts. Quantitative assay was used to determine MIC (Minimum inhibitory concentration) of extract against 7 reference strains. From the results of screening, Seven strains of actinomycetes that have the highest biological activity (Code: G244, G246, G261, G266, G278, G280 and G290) were chosen to be identified by morphological and phylogenetic based on 16S rRNA gene sequences. The results showed that 6 strains G246, G261, G266, G278, G280 and G290 belonged to the genus Streptomyces; and the strain G244 belonged to the genus Micromonospora. In particular, strains G244, G278, G280 were resistant 5/7 strains of microorganisms test, with values MICs from $2 \mu \mathrm{g} / \mathrm{mL}$ to $256 \mu \mathrm{g} / \mathrm{mL}$; and three strains G261, G266, G290 showed the inhibitory effect towards 4/7 strains of microorganisms test, with respective values MICs from $2 \mu \mathrm{g} / \mathrm{mL}$ to $256 \mu \mathrm{g} / \mathrm{mL}$. Moreover, six of the seven selected strains were highly resistant to yeast Candida albicans ATCC10231 with MIC values from $2 \mu \mathrm{g} / \mathrm{mL}$ to $256 \mu \mathrm{g} / \mathrm{mL}$. These results indicated that marine Actinomycetes in Vietnam are also a potential source to find bioactive substances.

Keywords: $16 \mathrm{~S}$ rRNA gene sequences, Actinomycetes, Antimicrobial activity, Micromonospora, Streptomyces

\section{INTRODUCTION}

Actinomycetes are diverse group of Gram positive bacteria that usually grow by filament formation. They belong to the order Actinomycetales with high $\mathrm{G}+\mathrm{C}(>55 \%)$ content in their DNA. In fact, the most common source of antibiotics is Actinomycetes which provide around two-third of naturally occurring antibiotics, including many of medical importance (Okami, Hotta 1988). Aquatic actinomycetes are of biological importance because of their efficiency in antibiotic production. They are considered highly valuable for producing various antibiotics and other therapeutically useful compounds with diverse biological activities. Many of the presently used antibiotics such as streptomycin, gentamicin, rifamycin and erythromycin are the products of actinomycetes. The genus Streptomyces is represented in nature by the largest number of species and varieties, producing the majority of known antibiotics among the family Actinomycetaceae. Streptomyces are well known sources of antibiotics and other important novel metabolites, including antifungal agents, antitumor agents, antihelminthic agents and herbicides (Lee et al., 2003; Thakur et al., 2007). 
Though the recent search for novel antibiotics have established approach of target based discovery using bacterial genomics, combinatorial chemistry, these powerful tools have not yet yielded any antibiotics approved for clinical use, and the prospects for their success are not encouraging (Baltz, 2007). Another way, programs aimed at the discovery of antibiotics from microbial sources have yielded an impressive number of compounds over the past 50 years, many of which have application in human medicine and agriculture (Busti et al., 2006). Therefore, the traditional method of screening antibiotics from microorganisms is still very effective (Baltz, 2007).

It is obvious that actinomycetes serve as an abundant source of bioactive compounds. In the future, manifold novel compounds would be potentially discovered from them. Herein, we reported on the isolation, taxonomic characterization, extraction fermentation broths with ethyl acetate of these actinomycete strains isolated from samples collected in Hue, Da Nang and Quang Nam of Vietnaman also reported on their antimicrobial activity.

\section{MATERIALS AND METHODS}

\section{Microorganism test}

The microorganisms used for antibacterial test were from ATCC Collection: Three Gram negative bacteria (Escherichia coli ATCC25922, Pseudomonas aeraginosa ATCC27853, Salmonella enteric ATCC13076), and three Gram positive bacteria (Enterococcus faecalis ATCC29212, Stapphylococus aureus ATCC25923, Bacillus cereus ATCC 13245 ), one yeast strain Candida albicans ATCC10231.

\section{Sample collection}

The marine samples were collected using Ponar from three locations in Hue, Da Nang and Quang Nam at $4-24 \mathrm{~m}$ depth with different geographic coordinates (Table 1), the water at temperatures was $26-29^{\circ} \mathrm{C}$. The samples were collected into $15 \mathrm{~mL}$ or $50 \mathrm{~mL}$ sterile Falcon tubes, preserved in ice-box and processed within $24 \mathrm{~h}$.

Table 1. Detail of the samples collected from three different locations: Hue, Da Nang and Quang Nam.

\begin{tabular}{|c|c|c|c|c|}
\hline Locations & geographic coordinates & No of samples & Water depth $(\mathrm{m})$ & Collection time \\
\hline Hue (Mui Tho Lo in Hai Van) & $16^{0} 13^{\prime} 3^{\prime \prime}-108^{0} 7^{\prime} 57^{\prime \prime}$ & 21 & $5-24$ & 26. 05. 2016 \\
\hline $\begin{array}{l}\text { Hue (Bai Chuoi, Son Cha in } \\
\text { Hai Van) }\end{array}$ & $16^{0} 13^{\prime} 1^{\prime \prime}-108^{0} 8^{\prime} 37^{\prime \prime}$ & 8 & 6 & 27. 05. 2016 \\
\hline $\begin{array}{l}\text { Hue (BanhTranh, Son Cha } \\
\text { in Hai Van) }\end{array}$ & $16^{0} 12^{\prime} 58^{\prime \prime}-108^{0} 7{ }^{\prime} 59^{\prime \prime}$ & 3 & 5 & 27. 05. 2016 \\
\hline $\begin{array}{l}\text { Quang Nam (Hon Tai in Cu } \\
\text { Lao Cham) }\end{array}$ & $15^{0} 54^{\prime} 13^{\prime \prime}-108^{0} 31^{\prime} 54^{\prime \prime}$ & 16 & 4 & 19. 09. 2016 \\
\hline $\begin{array}{l}\text { Quang Nam (Hon La in Cu } \\
\text { Lao Cham ) }\end{array}$ & $15^{0} 58^{\prime} 19^{\prime \prime}-108^{0} 27^{\prime} 7^{\prime \prime}$ & 11 & 3 & 01.10 .2016 \\
\hline $\begin{array}{l}\text { Quang Nam (Hon Mo in Cu } \\
\text { Lao Cham) }\end{array}$ & $15^{0} 55^{\prime} 50^{\prime \prime}-108^{0} 28^{\prime} 30^{\prime \prime}$ & 19 & $3-7$ & 01. 10. 2016 \\
\hline $\begin{array}{l}\text { Quang Nam (Hon Dai in Cu } \\
\text { Lao Cham) }\end{array}$ & $15^{0} 56^{\prime} 24^{\prime \prime}-108^{0} 28^{\prime} 56^{\prime \prime}$ & 24 & $4-90$ & 02. 10. 2016 \\
\hline Đa Nang (Son Tra) & $16^{0} 11^{\prime} 37-108^{0} 11^{\prime} 43$ & 5 & $16-20$ & 24. 08. 2016 \\
\hline $\begin{array}{l}\text { Đa Nang (Northeast of the } \\
\text { Son Tra) }\end{array}$ & $16^{0} 09^{\prime} 11-108^{0} 13^{\prime} 50$ & 23 & 10 & 24. 08. 2016 \\
\hline $\begin{array}{l}\text { Đa Nang (Northeast of the } \\
\text { Son Tra) }\end{array}$ & $16^{0} 34^{\prime} 50-108^{0} 11^{\prime} 4$ & 15 & 7 & 25. 08.2016 \\
\hline
\end{tabular}

\section{Isolation of actinomycetes}

First, $0.5 \mathrm{~g}$ of sample was suspended in $4.5 \mathrm{~mL}$ of sterile distilled water, homogenized by vortexing for $1 \mathrm{~min}$, and the suspension was treated using a wet-heat technique $\left(60^{\circ} \mathrm{C}\right.$ for $\left.6 \mathrm{~min}\right)$. Next, $0.5 \mathrm{~mL}$ of this suspension was transferred to another $4.5 \mathrm{~mL}$ sterile distilled water and this step was repeated to set up a ten fold dilution series to $10^{-3}$. At the final dilution step, aliquots of $50 \mu \mathrm{L}$ were spread on six different media including A1 (soluble starch: $10 \mathrm{~g} / \mathrm{L}$; yeast extract: $4 \mathrm{~g} / \mathrm{L}$ peptone: $2 \mathrm{~g} / \mathrm{L}$; instant ocean: 30 
g/L; agar: $15 \mathrm{~g} / \mathrm{L}$ ); M1 (soluble starch: $5 \mathrm{~g} / \mathrm{L}$; yeast extract: $2 \mathrm{~g} / \mathrm{L}$; peptone: $1 \mathrm{~g} / \mathrm{L}$; instant ocean: $30 \mathrm{~g} / \mathrm{L}$; agar: $15 \mathrm{~g} / \mathrm{L}$ ), SWA (instant ocean: $30 \mathrm{~g} / \mathrm{L}$; agar: 15 $\mathrm{g} / \mathrm{L}) ; \mathrm{A}+($ soluble starch: $10 \mathrm{~g} / \mathrm{L}$; yeast extract: $4 \mathrm{~g} / \mathrm{L}$; peptone: $2 \mathrm{~g} / \mathrm{L}$; instant ocean: $30 \mathrm{~g} / \mathrm{L} ; \mathrm{CaCO}_{3}: 1 \mathrm{~g} / \mathrm{L}$; agar: $15 \mathrm{~g} / \mathrm{L}$ ), SCA (soluble starch: $10 \mathrm{~g} / \mathrm{L} ; \mathrm{K}_{2} \mathrm{HPO}_{4}$ : $2 \mathrm{~g} / \mathrm{L} ; \mathrm{KNO}_{3}: 2 \mathrm{~g} / \mathrm{L}$; casitone: $300 \mathrm{mg} / \mathrm{L}$; $\mathrm{MgSO}_{4} \cdot 7 \mathrm{H}_{2} \mathrm{O}: 50 \mathrm{mg} / \mathrm{L} ; \mathrm{FeSO}_{4} \cdot 7 \mathrm{H}_{2} \mathrm{O}: 10 \mathrm{mg} / \mathrm{L}$; instant ocean: $30 \mathrm{~g} / 1 \mathrm{~L} \mathrm{CaCO}_{3}: 2 \mathrm{mg} / \mathrm{L}$; agar: $15 \mathrm{~g} / \mathrm{L}$ ), NZSG (soluble starch: $20 \mathrm{~g} / \mathrm{L}$; yeast extract: $5 \mathrm{~g} / \mathrm{L}$ glucose: $10 \mathrm{~g} / \mathrm{L}$; NZ amine A: $5 \mathrm{~g} / \mathrm{L}$; instant ocean: $30 \mathrm{~g} / \mathrm{L}$; agar: $15 \mathrm{~g} / \mathrm{L}$ ); ISP1 (soluble starch: $5 \mathrm{~g} / \mathrm{L}$; yeast extract: $2 \mathrm{~g} / \mathrm{L}$; casitone: $5 \mathrm{~g} / \mathrm{lL}$ instant ocean: $30 \mathrm{~g} / \mathrm{L}$; agar: $15 \mathrm{~g} / \mathrm{L}$ ), ISP2 (soluble starch: $5 \mathrm{~g} / \mathrm{L}$; yeast extract: $2 \mathrm{~g} / \mathrm{L}$; malt extract: $10 \mathrm{~g} / \mathrm{L}$; glucose: 10 $\mathrm{g} / \mathrm{L}$; instant ocean: $30 \mathrm{~g} / \mathrm{L}$; agar: $15 \mathrm{~g} / \mathrm{L})$. These media were supplemented with $50 \mu \mathrm{g} / \mathrm{mL}$ polymycin $\mathrm{B}$ and cycloheximide to inhibit Gram - negative bacterial and fungal contamination. After 21 days of aerobic incubation at $28^{\circ} \mathrm{C}$, the colonies of actinomycete strains were transferred onto A1 agar medium (Williams et al., 1965, 1971 ).

\section{Extraction crude and screening the antimicrobial activity of the extracts}

The actinomycetes strains were cultivated at $28^{\circ} \mathrm{C}$ in sterile $1000 \mathrm{~mL}$ flasks containing $500 \mathrm{~mL}$ media $\mathrm{A}^{+}$with glucose $1 \%$, pH 7.0, at $200 \mathrm{rpm}$. After 7 days of cultivation, the fermentation broths were filtered and then extracted 5 times with ethyl acetate. The extracts were evaporated under reduced pressure to yield crude extracts (Cédric et al., 2013).

Crude extracts were tested against the Grampositive bacteria (B. cereus ATCC13245, E. faecalis ATCC29212, S. aureus ATCC25923), the Gramnegative bacteria ( $P$. aeruginosa ATCC27853, E. coli ATCC25922, S. enterica ATCC13076) and the fungi C. albicans ATCC10231. The positive control was streptomycin for bacteria, and nystatin for fungi C. albicans ATCC10231. Quantitative assay was done by dilution method for determination of MIC (Minimum Inhibition Concentration) values of extracts against the test bacteria. MIC means the lowest concentration of extract at which the test microorganism did not show any visible. The density of cells was read at $610 \mathrm{~nm}$ and adjusted to an optical density (OD) of 0.04 for Gram-positive bacteria, and 0.05 for Gram-negative bacteria and $C$. albicans. Aliquots of $50 \mu \mathrm{L}$ of bacterial or fungal suspension were incubated with each crude extract for $24 \mathrm{~h}$ at $30^{\circ} \mathrm{C}$. The UV absorption of each sample was read at $610 \mathrm{~nm}$ and compared against the UV absorption of the media as control. MIC value was determined in wells with the lowest concentration of reagents that completely inhibits the growth of microorganisms after $24 \mathrm{~h}$ of incubation and was correctly identified based on data of cell turbidity measured by spectrophotometer Biotek and GraphPadPrism DaTa software (Hadacek et al., 2000).

\section{Identification of actinomycetes}

The actinomycete strains were grown for 14 days at $28^{\circ} \mathrm{C}$ on starch casein agar (SCA) and examined using scanning electron microscopy (model JSM-5410 LV; JEOL). Samples for scanning electron microscopy (SEM) were prepared as described by Itoh (1989).

Sequences of the 16S rRNA gene were used for identification of choosen strains. PCR amplifications were performed in a $25.0 \mu \mathrm{L}$ mixture containing: $16.3 \mu \mathrm{L}$ of $\mathrm{sdH}_{2} \mathrm{O}, 2.5 \mu \mathrm{L}$ of $10 \mathrm{X}$ PCR buffer, 1.5 $\mu \mathrm{L}$ of $25 \mathrm{mM} \mathrm{MgCl}_{2}, 0.5 \mu \mathrm{L}$ of $10 \mathrm{mM}$ dNTP's, 0.2 $\mu \mathrm{L}$ of Taq polymerase, $1.0 \mu \mathrm{l}$ for both $0.05 \mathrm{mM}$ of 9 F (5'-GAGTTTGATCCTGGCTCAG3') and 0.05 $\mathrm{mM}$ of 1541R (5'-AAGGAGGTGATCCAACC3') primers (Rajesh et al., 2013) and $2.0 \mu \mathrm{L}$ of genomic DNA. The reaction tube was then put into MJ Thermal Cycler, which had been programmed to preheat at $94^{\circ} \mathrm{C}$ for $3 \mathrm{~min}$, followed by 30 cycles of denaturation at $94^{\circ} \mathrm{C}$ for $1 \mathrm{~min}$, annealing at $60^{\circ} \mathrm{C}$ for $30 \mathrm{~s}$ and elongation at $72^{\circ} \mathrm{C}$ for $45 \mathrm{~s}$ before a final extension of $72^{\circ} \mathrm{C}$ for $10 \mathrm{~min}$. The estimated PCR product size was about $1500 \mathrm{bp}$. PCR products were purified by DNA purification kit (Invitrogen) then sequenced by DNA Analyzer (ABI PRISM 3100, Applied Bioscience). Gene sequences were handled by BioEdit v.2.7.5. and compared with bacterial $16 \mathrm{~S}$ rRNA sequences in GeneBank database by NBCI Blast program. The alignment was manually verified and adjusted prior to the construction of a phylogenetic tree. The phylogenetic tree was constructed by using the neighbor-joining the MEGA program version 4.1 (Saitou et al., 1987).

\section{RESULTS AND DISCUSSION}

\section{Isolation and screening the antimicrobial activity of of actinomycetes}

From 145 marine samples collected in Hue, Da Nang and Quang Nam, 81 actinomycete strains were isolated.These strains then were cultured and extracted to screen biological activity. From the 
results of screening, seven strains of actinomycetes that have the highest biological activity (Code:
G244, G246, G261, G266, G278, G280 and G290) were chosen (Table 2).

Table 2. Antimicrobial activity of crude ethyl acetate extracts from 7 strains.

\begin{tabular}{|c|c|c|c|c|c|c|c|c|}
\hline \multirow[t]{2}{*}{ S.No. } & \multirow[t]{2}{*}{ Isolates } & \multicolumn{3}{|c|}{ Gram-positive } & \multicolumn{3}{|c|}{ Gram-negative } & \multirow{2}{*}{\begin{tabular}{l}
\multicolumn{1}{c}{ Yeast } \\
C.albicans \\
ATCC10231
\end{tabular}} \\
\hline & & $\begin{array}{l}\text { E.faecalis } \\
\text { ATCC29212 }\end{array}$ & $\begin{array}{l}\text { S.aureus } \\
\text { ATCC25923 }\end{array}$ & $\begin{array}{l}\text { B.cereus } \\
\text { ATCC13245 }\end{array}$ & $\begin{array}{l}\text { E.coli } \\
\text { ATCC25922 }\end{array}$ & $\begin{array}{r}\text { P.aeruginosa } \\
\text { ATCC27853 }\end{array}$ & $\begin{array}{l}\text { S.enterica } \\
\text { ATCC13076 }\end{array}$ & \\
\hline & Unit & $\mathrm{MIC}(\mu \mathrm{g} / \mathrm{mL})$ & $\operatorname{MIC}(\mu \mathrm{g} / \mathrm{mL})$ & $\mathrm{MIC}(\mu \mathrm{g} / \mathrm{mL})$ & $\mathrm{MIC}(\mu \mathrm{g} / \mathrm{mL})$ & $\mathrm{MIC}(\mu \mathrm{g} / \mathrm{mL})$ & $\mathrm{MIC}(\mu \mathrm{g} / \mathrm{mL})$ & $\mathrm{MIC}(\mu \mathrm{g} / \mathrm{mL})$ \\
\hline 1 & G244 & 64 & - & 256 & 128 & - & 32 & 32 \\
\hline 2 & G246 & 64 & - & 128 & - & - & - & 32 \\
\hline 3 & G261 & 64 & - & 256 & - & 16 & - & 16 \\
\hline 6 & G280 & 256 & - & 256 & 16 & 32 & - & 2 \\
\hline 7 & G290 & - & - & 32 & - & 16 & 8 & 16 \\
\hline \multicolumn{2}{|c|}{ Steptomycin } & 256 & 256 & 128 & 32 & 256 & 128 & - \\
\hline \multicolumn{2}{|c|}{ Nistatin } & - & - & - & - & - & - & 8 \\
\hline
\end{tabular}

The result reveals that most of the isolates were active against both Gram positive and Gram negative bacteria. Strains G244, G278, G280 were resistant 5/7 strains of microorganisms test, with values MICs from $2 \mu \mathrm{g} / \mathrm{mL}$ to $256 \mu \mathrm{g} / \mathrm{mL}$; and three strains $\mathrm{G} 261$, G266, G290 showed the inhibitory effect towards 4/7 strains of microorganisms test, with respective values MICs from $2 \mu \mathrm{g} / \mathrm{mL}$ to $256 \mu \mathrm{g} / \mathrm{mL}$. In addition, six of the seven strains selected were highly resistant to $C$. albicans ATCC10231 with MIC values from 2 $\mu \mathrm{g} / \mathrm{mL}$ to $256 \mu \mathrm{g} / \mathrm{mL}$. Comparison of antimicrobial activity among screening strains in Hue, Quang Nam and Da Nang with isolated strains in the North - East Coast of Vietnam showed that: 7 strains of actinomycetes selected above have potent activity against both Gram-positive and Gram-negative bacteria. Of the 15 strains screened in the North-East Coast of Vietnam, only four strains of G057, G115, G119, and G120 were resistant to $P$. auruginosa ATCC27853 with a MIC value of $64-32 \mu \mathrm{g} / \mathrm{mL}$ (Le Thi Hong Minh et al., 2016). This result shows that the biological activity of the strains depends very much on geographic location during sample collection.

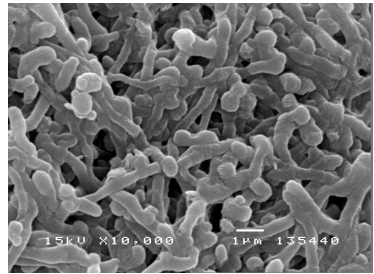

A

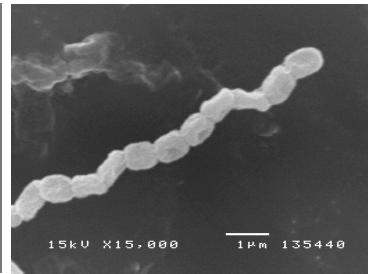

B

\section{Identification of actinomycetes by morphological} characteristic

The spore morphology is considered as one of the important characteristics in the identification of Streptomyces and it greatly varies among the species. It has been found that the majority of the marine isolates produced aerial coiled mycelia and the spores arranged in chains as already reported by Mukherjee and Sen, 2004 (Fig. 1B, 1C, 1D). Micromonospora species produced well-developed and branched substrate hyphae on yeast extract-malt extract medium, but no aerial hyphae. Spores were borne singly on the substrate hyphae having an approximate diameter of $0.5-1 \mu \mathrm{m}$. The spores were nodular and smooth on the surface and non-motile (Fig.1A).

The colors of the substrate mycelium were yellowish white to vivid orange and turned to brownish black to black after sporulation (Figure 2). The morphological characteristics of these isolates were consistent with their classification in the genus (Kawamoto et al., 1989).

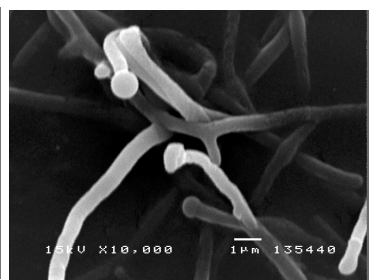

C

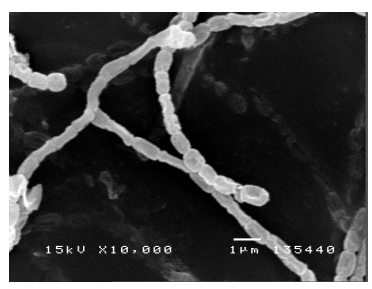

B

Figure 1. Scanning electron micrographs of the representative strains G244(A ); G246 (B); G266 (C), and G290 (D) grown on SCA agar for 2 weeks at $30^{\circ} \mathrm{C}$. 


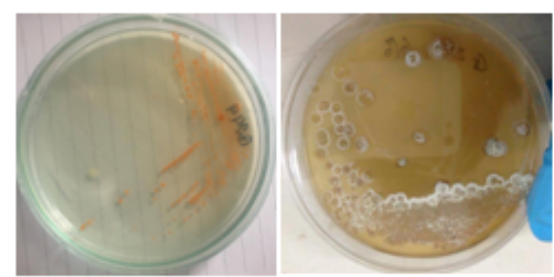

A

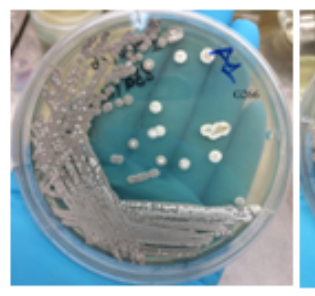

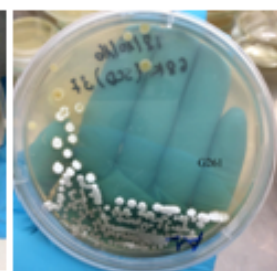

$\mathrm{C}$

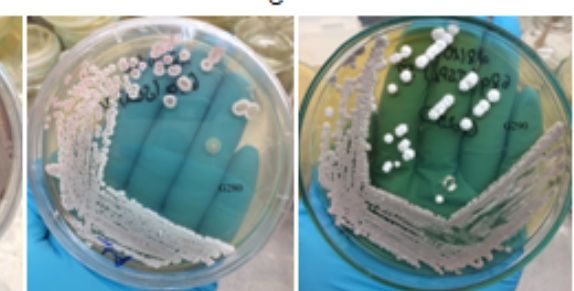

Figure 2. Morphological appearance of isolates. The colors of the substrate mycelium were vivid orange $A(G 244)$ and from white turned to brownish after sporulation B(G246), C(G261), D(G266), E(G278), F(G280) and G(G290).

\section{Identification of actinomycetes by phylogenetic based on $16 \mathrm{~S}$ rRNA gene sequences}

Seven potential isolates were selected for identification by $16 \mathrm{~S}$ rRNA gene sequencing. The obtained sequences were analysed by Bioedit program and compared with those in GenBank database. The obtained results showed that $16 \mathrm{~S}$ rRNA sequences of G246, G261, G266, G278, G280 and G290 strains exhibited high similarity (99\%) with genus Stretomyces spp; The strain G244 was identified ( $99 \%$ similarity) of $16 \mathrm{~S}$ rRNA gene sequence with genus Micromonospora in GenBank) (Figure 3).

Streptomyces is a genus of Gram-positive bacteria that grows in various environments, with a filamentous form similar to fungi. The morphological differentiation of Streptomyces involves the formation of a layer of hyphae that can differentiate into a chain of spores. The most interesting property of Streptomyces is the ability to produce bioactive secondary metabolites such as antifungals, antivirals, antitumoral, antihypertensives, and mainly antibiotics and immune suppressives (Patzer et al., 2010; Khan 2011). Another characteristic of the genus is complex multicellular development, in which their germinating spores form hyphae. Then, multinuclear aerial mycelium forms septa at regular intervals, creating a chain of spores (Ohnishi et al., 2008).

Marine environment contains a wide range of distinct Streptomyces that are not present in the terrestrial environment. Though some reports are available on antibiotic and enzyme production by marine actinomycetes, the marine environment is still a potential source for isolating new actinomycetes, which can yield novel bioactive compounds and industrially important enzymes (Cai et al., 2007).

In addition, Micromonospora species - the dominant actinomycetes are possible to be isolated from aquatic habitats such as streams, lake mud, river sediments, beach sands, sponge and marine sediments (Rifaat, 2003; Eccleston et al., 2008). Micromonospora species, together with Streptomyces species are best known for synthesizing antibiotics, especially aminoglycoside, enediyne, and oligosaccharide antibiotics. Thus, their impact on medicine is considerable. Of common antibiotics in the medical field, gentamicin and netamicin belong to the aminoglycoside antibiotics yielded by Micromonospora (Bérdy, 2005).

Research focused on marine environment has been gaining importance in recent years. However, still it has not been fully explored and there is tremendous potential to identify novel organisms with various biological properties. The present investigation showed that actinomycetes tentatively identified as Streptomyces species have strong antimicrobial activities against pathogenic bacteria (Sujatha et al., 2005; Ramesh et al., 2009). 


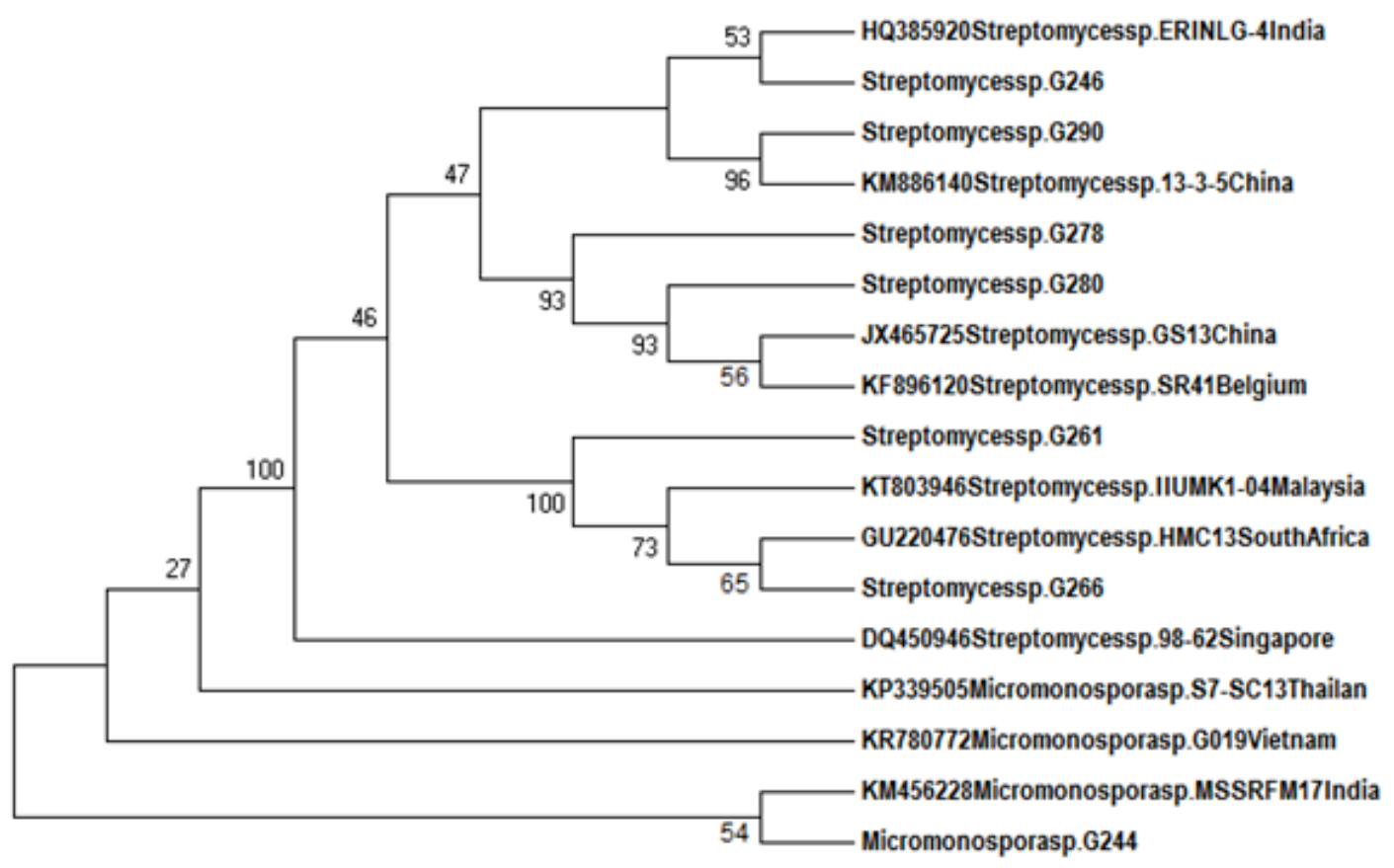

Figure 3. Neighbor-joining tree based on almost-complete 16S rRNA gene sequences showing relationships between the strains in groups and representative members of the genera Streptomyces and Micromonospora were used as an outgroup. The numbers on the branches indicate the percentage bootstrap values of 1,000 replicates; Bar, 0.01 substitutions per nucleotide position.

\section{CONCLUSION}

From 145 samples including sediments, sponges, soft corals, echinoderms and starfish collected from three sea areas of Vietnam: Hue, Da Nang, and Quang Nam, 81 strains of actinomycetes were isolated. Most of the isolates exhibited antimicrobial activity, seven strains of actinomycetes that have the highest biological activity were chosen to be identified by morphological and phylogenetic investigations based on 16S rRNA gene sequences. The strains G246, G261, G266, G278, G280, and G290 belonged to genus Stretomyces; strain G244 were identified as genus Micromonospora. Specifically, All of the seven strains were resistant from 4 to 5 out of 7 strains of microorganisms test, with values MICs from $2 \mu \mathrm{g} / \mathrm{mL}$ to $256 \mu \mathrm{g} / \mathrm{mL}$. In addition, six of the seven strains selected were highly resistant to yeast $C$ Albicans ATCC10231with MIC values from $2 \mu \mathrm{g} / \mathrm{mL}$ to $256 \mu \mathrm{g} / \mathrm{mL}$. Research results have shown that marine actinomycetes isolated from the marine environment of Vietnam promise to be a rich source of materials for secondary bioactive compounds.
Acknowledgements: This work was financially supported by the Vietnam Academy of Science and Technology (VAST). Code of project: VAST.TĐ.DLB.04/16-18.

\section{REFERENCES}

Baltz RH (2007) Antimicrobials from actinomycetes: Back to the future. Microbe 2(3): 125-131.

Bérdy J (2005) Bioactive microbial metabolites: a personal view. J Antibiot Tokyo 58: 1-26.

Busti E, Monociardini P, Cavaletti L, Bamonte R, Lazzarini A, Sosio M and Donadio S (2006) Antibioticproducing ability by representatives of a newly discovered lineage of Actinomycetes. Microbiology 152: 675-683.

Cai P, Kong F, Fink P, Ruppen ME, Williamson RT, Keiko T (2007) Polyene antibiotics from Streptomyces mediocidicus. J Nat Prod 70: 215-219.

Cédric O, Skylar C, Bindiya K, Mashal M A, Haipeng L, Anna O, Quan S, Van Cuong Pham, Catherine L S, Brian $\mathrm{T} \mathrm{M}$ and S. Alexander M (2013) Tool for characterizing bacterial protein synthesis inhibitors. Antimicrob Agents Chemother 57(12): 5994-6002. 
Eccleston G P, Brooks P R, Kurtboke D I (2008) The occurrence of bioactive micromonsoporae in aquatic habitats of the sunshine coast in Australia. Mar Drugs 6: 243-261.

Hadacek F, Greger H (2000) Test of antifungal natural products methodolagies, comparability of result and assay choise. Phytochem Anal 90: 137-147.

Itoh T, Kudo T, Parenti F, Seino A (1989) Amended description of the genus Kineosporia, based on chemotaxonomic and morphological studies. Int $J$ Syst Bacteriol 39: 168-173.

Khan ST (2011) Streptomyces associated with a marine sponge Haliclona sp.; biosynthetic genes for secondary metabolites and products. Environ Microbiol Black Sci Pub 13: 391-403.

Kawamoto I, Williams S T, Sharpe M E, Holt J G (1989) Bergey's Manual of Systematic Bacteriology 4: 2442-2450.

Lee HB, Kim CJ, Kim JS, Hong KS, Cho KY (2003) A bleaching herbicidal activity of methoxyhygromycin (MHM) produced by an actinomycete strain Streptomyces sp.8E-12. Lett Appl Microbiol 36: 387-391.

Le T H M, Vu T Q, Nguyen M A, Doan T M H, Murphy B T, Chau V M, and Pham V C (2016) Isolation, screening and identification of microorganisms having antimicrobial activity isolated from samples collected on seabed of Northeast Vietnam. Journal of Biotechnology 14(3): 539547.

Mukherjee G, Sen SK (2004) Characterization and identification of chitinase producing Streptomyces venezulae P10. Indian J Exp Biol 42: 541-544.

Ohnishi Y, Ishikawa J, Hara H (2008) Genome sequence of the streptomycin-producing microorganism Streptomyces griseus IFO $13350 . \quad J$ Bacteriol 190: 4050-4060.
Okami, Y and Hotta K (1988) Search and discovery of new antibiotics. In: Actinomycetes in biotechnology. Academic press London : 37-67.

Patzer SI, Volkmar B (2010) Gene cluster involved in the biosynthesis of griseobactin, a catechol-peptide siderophore of Streptomyces sp. ATCC 700974. J Bacteriol 192: 426-435.

Ramesh S, Rajesh M, Mathivanan N (2009) Characterization of a thermostable alkaline protease produced by marine Streptomyces fungicidicus MML1614. Bioprocess Biosyst Eng 32: 791-800.

Rajesh M M, Subbaiya R, Balasubramanian M (2013) Isolation and Identification of Actinomycetes Isoptericola variabilis from Cauvery River Soil Sample. Int J Curr Microbiol App Sci 2(6): 236-245.

Rifaat H M (2003) The biodiversity of actinomycetes in the River Nile exhibiting antifungal activity. $J$ Mediter Ecol.4: 5-7.

Saitou N, Nei M (1987) The neighbor-joining method: a new method for reconstructing phylogenetic trees. $\mathrm{Mol}$ Biol 4: 406-425.

Sujatha P, Bapiraju KV, Ramana T (2005) Studies on a new marine Streptomycete BT-408 producing polyketide antibiotic SBR-22 effective against methicillin resistant Staphylococcus aureus. Microbiol Res 160: 119-126

Thakur D, Yadav A, Gogoi BK, Bora T C (2007) Isolation and screening of Streptomyces in soil of protected forest areas from the states of Assam and Tripura, India, for antimicrobial metabolites. J Mycol Med 17:242-249.

Williams S T and Davies F L (1965) Use of antibiotics for selective isolation and enumeration of Actinomycetes in soil. J Gen Microbiol 38: 251-261.

Williams S T, Cross T (1971) Actinomycetes in: Methods in Microbiology. Academic Press (London) 4:295-334.

\title{
ĐİNH DANH VÀ HOATT TÍNH KHÁNG KHUẨN CỦA CÁC CHỦNG XA KHUẢN ĐƯợC PHÂN LẬP TỪ CÁC MẪU THU THẬP Ở VÙNG VEN BIỂN HUẾ, ĐÀ NÃ̃NG VÀ QUẢNG NAM
}

\author{
Cao Đức Tuấn ${ }^{1,2,3}$, Lê Thị Hồng Minh ${ }^{1}$, Vũ Thị Quyên ${ }^{1}$, Nguyễn Mai Anh ${ }^{1}$, Đoàn Thị Mai Hương ${ }^{1}$, \\ Châu Văn Minh ${ }^{1}$, Phạm Văn Cường ${ }^{1}$
}

${ }^{I}$ Viện Hóa sinh biển, Viện Hàn lâm Khoa học và Công nghệ Việt Nam

${ }^{2}$ Truờng Đại học Y duợc Hải Phòng

${ }^{3}$ Học viện Khoa học và Công nghệ, Viện Hàn lâm Khoa học và Công nghệ Việt Nam

\section{TÓM TẮT}

Vi sinh vật được quan tâm đặc biệt bởi khả năng sinh tổng hợp các hợp chất thứ cấp có giá trị cao và cung cấp cho chúng ta các cấu trúc hóa học mới lạ và đa dạng. Xạ khuẩn là nguồn sản xuất phổ biến nhất các chất kháng sinh, khoảng $2 / 3$ loại kháng sinh được phát hiện trong tự nhiên là từ xạ khuẩn. Trong nghiên cứu này, chúng tôi phân lập được 81 chủng xạ khuẩn từ 145 mẫu gồm: trầm tích, hải miên, san hô mềm, da gai và sao 
biển thu được từ 3 vùng biển của Việt Nam: Huế, Đà Nẵng và Quảng Nam. Các chủng đã được lên men trong môi trường $\mathrm{A}^{+}$và môi trường lên men được chiết xuất 5 lần với ethyl acetate. Các chất chiết xuất đã bay hơi dưới áp suất giảm để tạo ra các cặn chiết thô. Phương pháp định lượng được sử dụng để xác định MIC (nồng độ ức chế tối thiểu) của cặn chiết đối với 7 chủng vi sinh vật kiểm định. Từ kết quả sàng lọc, Từ các kết quả sàng lọc, bảy chủng actinomycetes có hoạt tính sinh học cao nhất (Mã số: G244, G246, G261, G266, G278, G280 và G290) được lựa chọn để định danh bằng hình thái học và phát sinh loài dựa trên trình tự gen $16 \mathrm{~S}$ rRNA. Kết quả cho thấy 6 chủng G246, G261, G266, G278, G280 và G290 thuộc về chi Streptomyces; và chủng G244 thuộc chi Micromonospora. Đặc biệt, chủng G244, G278, G280 đã kháng được 5/7 chủng vi sinh vật, với giá trị MICs từ $2 \mu \mathrm{g} / \mathrm{mL}$ đến $256 \mu \mathrm{g} / \mathrm{mL}$; và ba chủng G261, G266, G290 cho thấy tác dụng ức chế đối với 4/7 chủng vi sinh vật kiểm định, với giá trị tương ứng MICs từ $2 \mu \mathrm{g} / \mathrm{mL}$ đến $256 \mu \mathrm{g} / \mathrm{mL}$. Ngoài ra, sáu trong số bảy chủng được lựa chọn có hoạt tính ức chể nấm Candida albicans ATCC10231 rất cao với giá trị MICs từ $2 \mu \mathrm{g} / \mathrm{mL}$ đến $256 \mu \mathrm{g} / \mathrm{mL}$. Những kết quả thu được cho thấy rằng các chủng xạ khuẩn biển ở Việt Nam cũng là nguồn nguyên liệu tiềm năng để tìm kiếm các chất có hoạt tính sinh học. 